\title{
Gambaran Darah Lengkap dan Profil Lipid pada Anak Sekolah Dasar dengan Obesitas di Denpasar
}

\author{
Ida Bagus Mudita
}

Latar belakang. Prevalensi obesitas meningkat baik di negara maju maupun negara berkembang. Di Indonesia, prevalensi obesitas menunjukkan peningkatan baik di perkotaan maupun di pedesaan. Keadaan obesitas ini merupakan kondisi tubuh yang akan berdampak buruk pada kesehatan selanjutnya dan keadaan ini meningkatkan risiko penyakit kardiovaskular. Dislipidemi adalah kondisi yang mengikuti keadaan obesitas dengan terjadinya gangguan metabolisme lipid yang ditandai dengan perubahan absorbsi lipid plasma.

Tujuan. Mengetahui gambaran darah tepi dan profil lipid pada anak sekolah dasar dengan obesitas di Denpasar, Bali.

Metoda. Penelitian ini menggunakan rancangan potong lintang. Pemilihan sampel dengan menggunakan teknik cluster random sampling yang dilakukan di 6 Sekolah Dasar yang dipilih secara random di Denpasar mulai Agustus sampai dengan Desember 2004. Pengukuran darah dan profil lipid dilakukan satu kali pada anak sekolah dasar dengan obesitas. Dikatakan obesitas bila indeks masa tubuh ${ }^{3}$ persentil ke-95, dislipidemia bila kadar total kolesterol ${ }^{3} 170 \mathrm{mg} . \mathrm{dl}$ dan/atau kadar LDL kolesterol ${ }^{3} 110 \mathrm{mg} / \mathrm{dl} \mathrm{dan} /$ atau kadar HDL kolesterol 3200 mg/dl, dan anemia bila kadar haemoglobin < $12 \mathrm{~g} / \mathrm{dl}$ Hasil. Didapatkan 140 (11,7\%) anak obes, dari 1200 anak sekolah dasar. Prevalensi dislipidemia berdasarkan salah satu dan/atau lebih indikator lipid serum didapatkan $84,7 \%$. Dislipidemi oleh karena peningkatan kolesterol total $60,6 \%$, trigliserida $24,5 \%$, LDL-kolesterol 47,9\% dan HDL-kolesterol 73,4\%. Tidak didapat adanya anemia pada semua subyek.

Kesimpulan. Didapatkan prevalensi obesitas $11,7 \%$, dislipidemia $84,7 \%$, dan tidak didapatkan anemia.

Kata kunci: obesitas, indeks massa tubuh, darah lengkap, profil lipid

besitas pada anak telah menjadi masalah kesehatan beberapa dekade terakhir. Prevalensi obesitas meningkat baik di negara maju

\footnotetext{
Alamat korespondensi:

Dr. Ida Bagus Mudita,

Bagian/SMF Ilmu Kesehatan Anak, FK Unud/RS Sanglah Denpasar, Jalan P Nias, Denpasar.

Telepon. (0361)227911-227915 Pes. 128. Fax. (0361)244038
}

maupun negara berkembang. ${ }^{1}$ Prevalensi obesitas pada anak usia 16-17 tahun di Amerika Serikat dalam tiga dekade terakhir meningkat dari 7,6\%-10\% menjadi 13\%-14\%. Di Cina pada tahun 1996, prevalensi obesitas pada anak prasekolah (obesitas ditentukan sebagai berat sesuai usia $>120 \%$ dari rerata nilai berdasarkan National Center for Health Statistics (NCHS), 2,2\% pada anak laki-laki dan 1,9\% anak perempuan. Lebih lanjut lagi, peningkatan prevalensi obesitas per tahun dari tahun 1986 sampai 1996 
10,0\% pada laki-laki dan 8,7\% anak perempuan. ${ }^{2} \mathrm{Di}$ Indonesia, prevalensi obesitas pada balita menurut Survei Kesehatan Nasional (SUSENAS) menunjukkan peningkatan baik di perkotaan maupun pedesaan, pada tahun 1992 di perkotaan didapatkan prevalensi obesitas sebesar 6,3\% pada laki-laki dan 8\% pada perempuan. Prevalensi obesitas di 27 propinsi pada tahun 1995 adalah 4,6\%. ${ }^{1}$ Di RS Dr. Cipto Mangunkusumo Jakarta (1988) dilaporkan prevalensi obesitas sekitar $16 \%$ pada pasien-pasien rawat jalan. ${ }^{1}$ Rubiana $(1995)^{3}$ di Denpasar melaporkan prevalensi obesitas pada anak SD 14\%, sedangkan pada anak yang lebih besar dilaporkan oleh Suparyatha $(2004)^{4}$ adalah sekitar 6,5\%.

Obesitas menurut World Health Organisation (WHO) adalah suatu kondisi terjadi akumulasi lemak yang banyak dalam tubuh yang akan berdampak buruk pada kesehatan selanjutnya. ${ }^{5}$ Obesitas pada anak meningkatkan risiko obesitas pada remaja dan berhubungan dengan faktor risiko penyakit kardiovaskular seperti hipertensi, diabetes melitus, dan dislipidemia. Oleh karena itu pencegahan awitan obesitas selama usia muda penting dalam mengurangi risiko penyakit jantung koroner pada kehidupan lebih lanjut. . $^{-11}$

Dua penelitian epidemiologi pada tahun 1960-an menyebutkan adanya hubungan antara anemia defisiensi besi dengan obesitas pada anak dan remaja. Sebuah penelitian potong lintang mendapatkan bahwa anak dan remaja obese dengan indeks massa tubuh (IMT) $>97$ persentil memiliki kejadian anemia defisiensi besi $>50 \%$. Beberapa faktor yang dapat menjelaskan hubungan kegemukan dengan anemia defisiensi besi adalah faktor genetik, kurangnya pemecahan mioglobin sehingga menurunkan jumlah besi yang dilepaskan pada darah, kurangnya asupan makanan yang kaya besi dan pertumbuhan yang lebih cepat sehingga menyulitkan penyimpanan besi pada tubuh. ${ }^{12}$

Obesitas ditandai dengan adanya komposisi lemak tubuh yang tinggi atau sangat tinggi. Lemak disimpan dalam tubuh dalam jaringan adiposa. Timbunan lemak yang banyak dalam tubuh akan dapat menimbulkan dampak yang buruk pada kesehatan. ${ }^{6,13}$ Peningkatan risiko penyakit kardiovaskular terjadi jika prosentase lemak tubuh lebih dari 30\% pada anak wanita dan lebih dari 25\% pada anak laki-laki. ${ }^{14}$ Dislipidemia adalah kondisi yang mengikuti obesitas terjadi gangguan metabolisme lipid yang ditandai dengan perubahan fraksi lipid dalam plasma. ${ }^{15,16} \mathrm{Pada}$ penelitian terhadap 9617 anak usia 5-17 tahun oleh
Bogalusa Heart Study didapatkan adanya korelasi obesitas yang sangat kuat dengan aterogenik dislipidemia (peningkatan kadar trigliserida dan HDLkolesterol yang rendah). ${ }^{10,17}$

Tujuan penelitian ini adalah untuk mengetahui gambaran darah lengkap dan profil lipid pada anak sekolah dasar dengan obesitas di Denpasar, Bali.

\section{Metoda}

Penelitian ini menggunakan rancangan potong lintang. Subyek penelitian adalah anak Sekolah Dasar di Denpasar dengan obesitas, dipilih dengan teknik cluster random sampling. Terpilih dua SD/kecamatan untuk mewakili 3 kecamatan di Denpasar yang dipilih secara acak. Penelitian dilakukan pada bulan Agustus sampai Desember 2004. Kriteria inklusi adalah anak sekolah dasar dengan obesitas dan mendapat ijin tertulis dari orangtuanya untuk mengikuti penelitian. Apabila anak menderita diabetes melitus, penyakit ginjal, hipotiroidisme, obstruksi saluran empedu, minum obat-obatan seperti glukokortikoid, diuretik, propanolol, dan data tidak lengkap; tidak diikutsertakan dalam penelitian.

\section{Cara dan alat pengumpulan data}

- Untuk mendapatkan anak dengan obesitas dilakukan pemeriksaan pendahuluan berupa pemeriksaan antropometri dan pencatatan data dasar yang kemudian dilanjutkan dengan penentuan status obese berdasarkan index massa tubuh sesuai umur dan jenis kelamin. Pengukuran darah lengkap dan profil lipid dilakukan satu kali oleh petugas dari laboratorium klinik Prodia. Sebelum pengambilan sampel darah responden diwajibkan puasa selama 10 jam. Sampel darah diambil $7 \mathrm{ml}$ dan dimasukkan ke dalam tabung blood vein vaccum-venoject. Kadar kolesterol total, trigliserida, HDL-kolesterol dan LDL-kolesterol diperiksa dengan teknik enzimatis dengan alat Hitachi 917.

\section{Definisi operasional variabel}

- Obesitas adalah status gizi dimana indeks massa tubuh $\geq$ persentil ke-95.

- Index Massa Tubuh (IMT) dihitung berdasarkan rumus berat badan $(\mathrm{kg})$ dibagi hasil kwadrat dari tinggi badan $($ meter $)=\mathrm{BB} /\left(\mathrm{TB}^{2}\right)$. Hasil perhitungan kemudian ditulis dalam kurve normo- 
gram Index Massa Tubuh sesuai yang ditetapkan Centers of Disease Control and Prevention (CDC) berdasarkan umur dan jenis kelamin. Disebut obes bila IMT ${ }^{3}$ persentil ke-95 sesuai dengan umur dan jenis kelamin. ${ }^{2}$

Umur adalah ditentukan berdasarkan tanggal lahir yang tercantum pada buku raport anak dihitung dari saat pemeriksaan (umur kronologis).

Berat badan diukur dengan menggunakan timbangan portable merek Tristar dengan tingkat kepekaan $0,1 \mathrm{~kg}$. Anak ditimbang dalam keadaan memakai pakaian seragam sekolah tanpa sepatu, hasil pengukuran merupakan rerata dari pengukuran yang dilakukan sebanyak 3 kali.

Tinggi badan diukur dengan menggunakan meteran plastik yang ditempelkan di dinding, pada saat diukur anak berdiri tegak, merapat ke tembok, kedua kaki tertutup rapat degan tumit menyentuh tembok dan tanpa alas kaki.

Diabetes melitus adalah anak yang mempunyai riwayat polifagi, polidipsi, dan poliuri dan mendapat obat anti diabetes.

Penyakit ginjal adalah anak dengan sindrom nefrotik, glomerulonefritis, atau gagal ginjal.

- Dislipidemia kadar total kolesterol $\geq 170 \mathrm{mg} / \mathrm{dl}$ dan/atau kadar LDL kolesterol $\geq 110 \mathrm{mg} / \mathrm{dl}$ dan/ atau kadar HDL kolesterol $\geq 200 \mathrm{mg} / \mathrm{dl}$.

- Profil lipid berdasarkan hasil pemeriksaan kadar lipid dalam darah yang terdiri dari kolesterol total, trigliserida, LDL-kolesterol dan HDL-kolesterol.

- Anemia apabila kadar $\mathrm{Hb}<12 \mathrm{~g} / \mathrm{dL} .^{18-21}$

\section{Analisis statistik}

Data dasar meliputi data antropometri, demografi, profil lipid terdiri dari kolesterol total (TC), trigrliserida (TG), kolesterol HDL (HDL-C), kolesterol LDL (LDL-C), apolipoprotein-B, ratio LDL/Apolipoprotein-B, dan ratio kolesterol total/HDL, darah perifer meliputi leukosit, white blood count (WBC), red blood count (RBC), hemoglobin (HGB), hematokrit (HCT), red distribution weidth (RDW-CV). Karakteristik dasar responden dan hasil pemeriksaan profil lipid dan darah tepi disajikan dalam bentuk tabel dan narasi. Semua data diolah dengan menggunakan program komputer, disajikan dalam bentuk narasi dan tabel.

\section{Hasil}

Dari 6 sekolah dasar yang terpilih, didapatkan 1200 anak yang dilakukan pemeriksaan antropometri dan sebanyak 140 orang $(11,7 \%)$ diantaranya dengan status obes berdasarkan IMT. Dari 140 anak hanya 72 orang yang diikutkan untuk pemeriksaan darah lengkap dan lipid serum, 46 orang tidak diikutkan dalam penelitian karena tidak mendapat persetujuan orangtua dan 22 orang anak tidak mempunyai data yang lengkap sehingga dikeluarkan dari penelitian. Karakteristik dasar responden tertera pada Tabel 1 .

Dari hasil pemeriksaan darah perifer lengkap, tidak didapatkan adanya kejadian anemi pada seluruh sampel penelitian (Tabel 2).

Prevalensi dislipidemia berdasarkan salah satu dan/atau lebih indikator lipid serum dalam penelitian ini didapatkan sebesar 84,7\%. Dislipidemi oleh karena peningkatan kolesterol total 60,6\%, trigliserida 24,5\%, LDL-kolesterol 47,9\% dan HDLkolesterol $73,4 \%$. Rerata serta rasio profil lipid tampak pada Tabel 3.

Tabel 1. Karakteristik dasar responden

\begin{tabular}{lc}
\hline Karakteristik subyek & $\begin{array}{c}\text { Rerata }(\mathrm{SB}) \\
\mathbf{n}=72\end{array}$ \\
\hline Usia (tahun), rerata (SD) & $9.56( \pm 1.4)$ \\
Jenis kelamin, laki-laki $\mathrm{n}(\%)$ & $45(62.5)$ \\
Berat badan (kg), rerata (SD) & $47,1( \pm 9,8)$ \\
Tinggi badan (cm), rerata (SD) & $136,8( \pm 12,4)$ \\
Index massa tubuh $\left(\mathrm{kg} / \mathrm{m}^{2}\right)$ & \\
$-<25, \mathrm{n}(\%)$ & $39(54.2)$ \\
$-25-29, \mathrm{n}(\%)$ & $30(41.7)$ \\
$->29, \mathrm{n}(\%)$ & $3(4.1)$ \\
\hline
\end{tabular}

Tabel 2. Gambaran darah lengkap anak SD yang obese di Denpasar

\begin{tabular}{lc}
\hline Jenis pemeriksaan & $\begin{array}{c}\text { Rerata }(\mathrm{SB}) \\
\mathbf{n}=72\end{array}$ \\
\hline WBC $\left(10^{3} / \mathrm{uL}\right)$, & $8.67( \pm 35)$ \\
RBC $\left(10^{6} / \mathrm{uL}\right)$, & $4.93( \pm 3.3)$ \\
HGB $(\mathrm{g} / \mathrm{dL})$, & $13.04( \pm 4.8)$ \\
HCT $(\%)$, & $41.04( \pm 19,3)$ \\
RDW-CV $(\%)$, rerata & $13.59( \pm 3.5)$ \\
\hline
\end{tabular}

$\mathrm{WBC}=$ white blood cell, $\mathrm{RBC}=$ red blood cell, $\mathrm{HGB}=$ hemoglobin,

$\mathrm{HCT}=$ hematokrit, $\mathrm{RDW}-\mathrm{CV}=$ red distribution width 
Tabel 3. Profil lipid anak SD obese di Denpasar

\begin{tabular}{lc}
\hline Jenis pemeriksaan lipid & $\begin{array}{c}\text { Rerata }(\mathrm{SB}) \\
\mathbf{n}=72\end{array}$ \\
\hline Total kolesterol $(\mathrm{mg} / \mathrm{dL})$, & $184.8( \pm 37.3)$ \\
Trigliserida $(\mathrm{mg} / \mathrm{dL})$, & $133.4( \pm 42.8)$ \\
HDL-kolesterol $(\mathrm{mg} / \mathrm{dL})$, & $46.4( \pm 9.3)$ \\
LDL-kolesterol $(\mathrm{mg} / \mathrm{dL})$, & $129.5( \pm 39.5)$ \\
Apolipoprotein-B $(\mathrm{mg} / \mathrm{dL})$, & $80.11( \pm 20.8)$ \\
Rasio LDL/Apolipoprotein-B & $1.45( \pm 0.3)$ \\
Rasio total kolesterol/HDL & $3.73( \pm 0.8)$ \\
\hline
\end{tabular}

\section{Diskusi}

Dari beberapa penelitian sebelumnya telah dapat dibuktikan bahwa adanya peningkatan IMT pada masa kanak-kanak yang merupakan prediktor terjadinya obesitas di kemudian hari. ${ }^{11}$ Sekitar sepertiga anak yang obese akan berlanjut sampai dewasa. ${ }^{22}$ Obesitas pada anak sekolah di Denpasar telah beberapa kali diteliti. Prevalensi dilaporkan berkisar 6,5\% sampai 16\%.,4 Pada penelitian ini didapatkan prevalensi obesitas pada anak sekolah dasar $11,7 \%$. Jika dibandingkan dengan angka nasional di 27 propinsi sesuai dengan SUSENAS 1995 prevalensi obesitas pada balita sebesar 4,6\% ${ }^{23}$ maka angka prevalensi di Denpasar ini tampak lebih tinggi. Namun karena terdapat kecenderungan bahwa dengan bertambahnya usia anak angka prevalensi obesitas juga meningkat, ${ }^{1}$ maka angka yang kami dapatkan tidaklah berarti jauh lebih tinggi dari laporan tersebut karena sampel kami adalah anak-anak usia 613 tahun. Prevalensi sebesar 27,5\% didapatkan pada penelitian yang dilakukan oleh Meilany, ${ }^{24}$ pada tahun 2002 pada anak SD di Jakarta Timur .

Komorbiditas yang sering berhubungan dengan obesitas pada populasi anak-anak adalah peningkatan tekanan darah, dislipidemia, dan meningkatnya faktorfaktor yang berhubungan dengan resistensi insulin dan diabetes tipe 2. ${ }^{6,11}$ Timbunan lemak berpotensi untuk terjadinya dislipidemi yang merupakan salah satu faktor risiko penyakit kardiovaskular. ${ }^{25}$ Dislipidemi merupakan suatu kondisi yang mengikuti obesitas yaitu terjadi gangguan metabolisme lipid yang ditandai dengan perubahan fraksi lipid dalam plasma. Angka dislipidemi yang tinggi pada anak obese merupakan faktor peramal yang kuat untuk mendapatkan risiko penyakit kardiovaskuler selanjutnya. ${ }^{25,26}$ Pada obesitas bisa terjadi peningkatan lipid kolesterol, trigliserida, maupun LDL-kolesterol. Namun pada anak obesitas lebih banyak terjadi peningkatan trigliserida dan penurunan HDL-kolesterol, dan abnormalitas ini ditandai dengan terdistribusinya lemak pada bagian sentral. ${ }^{27}$ Pada penelitian ini, didapatkan prevalensi dislipidemi yang lebih tinggi jika dibandingkan dengan penelitian sebelumnya. Suparyatha $(2004),{ }^{4}$ melaporkan 59\% dislipidemi pada anak-anak SMP, Meilany dkk (2002), ${ }^{24}$ melaporkan sebanyak 33\% dislipidemi pada anak SD di Jakarta Timur. Hal ini bisa terjadi oleh karena adanya variasi umur, demografi maupun proporsi jenis kelamin.

Pada penelitian ini tidak didapatkan adanya anemia. Sedangkan pada penelitian Nead dkk, ${ }^{12}$ kejadian anemia defisiensi besi $9,1 \%$ pada anak kelebihan berat badan berumur 12-16 tahun, 6,2\% pada umur 2-5 tahun dan disimpulkan terjadinya peningkatan kejadian anemia defisiensi besi pada anak yang kelebihan berat badan.

Kelemahan dari penelitian ini tidak dilakukannya pemeriksaan darah yang lebih lengkap untuk mendeteksi adanya anemia defisiensi besi pada anak obese yaitu pemeriksaan serum iron dan total iron binding capacity. Maka setelah penelitian pendahuluan ini perlu dilakukan penelitian lanjutan untuk memastikan hal tersebut.

\section{Kesimpulan}

Prevalensi anak obese pada penelitian ini didapatkan sebesar $11,7 \%$ dengan prevalensi dislipidemia sebesar $84,7 \%$. Tidak didapatkan adanya anemia.

\section{Daftar Pustaka}

1. Sjarif DR. Obesitas pada anak dan permasalahannya. Dalam: Trihono PP, Purnamawati S, Syarif DR, penyunting. Hot Topics in Pediatrics II. Naskah Lengkap Pendidikan Kedokteran Berkelanjutan Ilmu Kesehatan Anak XLV. FKUI; 2002 18-19 Pebruari; Jakarta: Balai Penerbit FKUI, 2002.

2. He Q, Ding ZY, Fong DYT. Blood pressure is associated with body mass index in both normal and obese children. Hypertension 2000; 36:15-70.

3. Rubiana. Gambaran klinis dan profil lipid serum pada anak obesitas di Sekolah Dasar Cipta Darma Denpasar, Bali. Denpasar: Lab. IKA FK UNUD, 1996. 
4. Suparyatha IBG. Dyslipidaemia dan faktor-faktor terkait pada remaja SMP Obese di Kotamadya Denpasar Bali. Thesis. Denpasar: Lab. IKA FK UNUD, 2004.

5. World Health Organization. Obesity: preventing and managing the global epidemic. Report on a WHO Consultation on Obesity, Geneva, 3-5 June 1997. WHO/ NUT/NCD/98.1. Geneva: WHO.

6. Suandi IKG. Obesitas pada remaja. Dalam: Soetjiningsih, penyunting. Buku ajar tumbuh kembang remaja dan permasalahannya. Jakarta: CV Sagung Seto, 2004. h. 77-86.

7. Rossner S. Obesity: the disease of the twenty-first century. International Journal of Obesity \& Related Metabolic Disorders: J Int Ass for the Study of Obesity 2002; 26(Suppl 4):S2-4.

8. Anonimus. Obesity task force (serial online). Diakses 15 Agustus 2005. Didapat dari URL: http://www. obesite.chaire.ulaval.ca/iotf.htm.

9. Dietz WH. Health consequences of obesity in youth: Childhood predictors of adult disease. Pediatrics 1997; 102:518-24.

10. Daniel SR, Arnett DK, Eckel RH, Gidding SS, Hayman LL, Kumanyika S, dkk. Overweight in children and adolescent. Circulation 2005; 111:1999-2012.

11. Deckelbaum RJ, Williams CL. Childhood obesity: The health issue. Obesity Research 2001; 9(suppl): 239s-43s.

12. Nead KG, Halterman JS, Kaczorowski JM. Overweight children and adolescent: a risk group for iron deficiency. Pediatrics 2004; 114:104-8.

13. Deurenberg P, Yap M. The assessment of obesity: methods for measuring body fat and global prevalence of obesity. Best Practice \& Research Clinical Endocrinology \& Metabolism 1999; 13:1-11.

14. Dwyer T, Blizzard CL. Defining obesity in children by biological endpoint rather than population distribution. J Int Ass for the Study of Obesity 1996; 20:472-80.

15. Miller J, Rosenbloom A, Silverstein J. Childhood obesity. JCEM 2004; 89:4211-8.

16. Terbakorec AM, Coates PM, Corner JA. Disorders of lipoprotein metabolism and transport. Dalam: Nelson WE, Behrman RE, Kliegman RM, Arvin AM, penyunting. Nelson textbook of pediatrics. Edisi ke-16. Philadelphia: W.B. Saunders Company, 2000. h. 377-84.

17. Freedman DS, Khan LK, Dietz WH, Srinivasan SR, Berenson GS. Relationship of childhood obesity to coro- nary heart disease risk factors in adulthood: The Bogalusa heart study. Pediatrics 2001; 108:712-8.

18. Raspati H, Reniarti L, Susanah S. Anemia defisiensi besi. Dalam: Permono HB, Sutaryo, Ugrasena IDG, penyunting. Buku ajar hematologi-onkologi anak. Jakarta, Balan penerbit IDAI, 2005. h. 30-43.

19. Barness LA, Curran JS. Nutrisi. Dalam: Nelson WE, Behrman RE, Kliegman R, penyunting. Nelson Ilmu Kesehatan Anak. Jakarta, Penerbit buku kedokteran EGC, 1996. h. 178-232.

20. Soemantri Ag. Epidemiology of iron deficiency anaemia. Dalam: Triasih R, penyunting. Anemia defisiensi besi. Yogyakarta: MEDIKA Fakultas Kedokteran UGM, 2005. h. 8-28.

21. Kisworini P, Mulatsih S. Clinical guideline anemia defisiensi besi. Dalam: Triasih R, penyunting. Anemia defisiensi besi. Yogyakarta: MEDIKA Fakultas Kedokteran UGM, 2005. h. 81-95.

22. Kotani K, Nishida M, Yamashita S. Two decades of annual medical examinations in Japanese obese children: do obese children grow into obese adult?. Int J Obes Relat Metab Disord 1997; 21:912-21.

23. Satoto, Karjati S, Darmojo B, Tjokroprawiro A, Kodyat BA. Gemuk, Obesitas dan Penyakit Degeneratif: epidemiologi dan strategi penanggulangan. Widyakarya Nasional Pangan dan Gizi VI. Serpong 17-20 Februari, 1998:787-808.

24. Meilany TA, Tambunan T, Soedibjo S. Clinical and laboratory profiles of obese elementary school children. Dalam: Budi KY, Nilawati, Widnyana, Anom A, penyunting. Proceedings of the young researcher award: Department of Child Health Sanglah Hospital School Medicine, Udayana University, 2002:33-42.

25. Bandini LG, Must A, Phillips SM, Naumova EN, Dietz WH. Relation of Body Mass Index and Body Fatness to Energy Expenditure: Longitudinal Changes from Preadolescence Through adolescence. Am J Clin Nutr 2004; 80:1262-9.

26. Mahardita IG, Suandi IKG. Lipid profil with obesity at Denpasar elementary school. Dalam: Garna H, Melinda $\mathrm{H}$, penyunting. KONIKA XIII, IDAI, Bandung. 2005:246. (abstrak)

27. Slyper AH. Childhood obesity, adipose tissue distribution, and the pediatric practitioner. Pediatrics 1998; 102:1-9. 